\title{
Regression equations for the estimation of the meat and fat content in broiler carcasses
}

\author{
R. Bochno, Jolanta Rymkiewicz and Maria Janiszewska
}

\author{
Department of Breeding Methods and Animal Improvement, \\ University of Agriculture and Technology \\ Oczapowskiego 5,10-718 Olsztyn. Poland
}

(Received 18 May 1998; accepted 19 November 1998)

\section{ABSTRACT}

Sixty-seven male and sixty-seven female broiler chickens were fed to appetite with standard feed mixtures and reared to six weeks of age. After the end of the rearing period, the broilers were slaughtered and their carcasses dissected into meat, skin plus subcutaneous fat, intramuscular fat, and bones.

The weight of the skin plus subcutaneous fat from the carcass without the wings $\left(\mathrm{X}_{4}\right)$, and the weight of the skinless carcass $\left(\mathrm{X}_{3}\right)$ are good indicators of fat content $(\check{Z})(\mathrm{r}=0.97)$ and meat content (Y) $(r=0.96)$, respectively, of whole broiler carcasses. These parameters are easy to determine.

The following equations can be recommended for experimental determinations:

$$
\hat{\mathrm{Y}}=0.6915 \mathrm{X}_{3}-18.56 \text { and } \breve{Z}=1.1452 \mathrm{X}_{4}+21.05
$$

KEY WORDS: broiler chickens, carcass, meat, fat, regression cquations

\section{INTRODUCTION}

From the point of view of consumers, broiler chickens have too much fat (Leenstra, 1986). This is the result of both genetic and environmental factors. For this reason, in addition to improving genotypes of breeding flocks, numerous experiments are being undertaken to improve the conditions under which the birds are maintained to ensure good meat quality. The chickens that are used in such experiments should be evaluated in terms of carcass meat and fat contents. The most exact method of determining the particular tissue components is detailed dissection, but it is laborious and costly. This is why simple methods are needed that will allow the estimation of the meat and fat contents of chicken carcasses. 
In numerous studies carried out to date, the suitability of various traits of both live and slaughtered birds for the assessment of carcass meat and fat content has been determined. It was found, among others, that among traits of live birds, breast muscle thickness is a good indicator of the meat content of carcasses (Pingel and Heimpold, 1983), while fat content is reflected in blood triglyceride levels (Książkiewicz et al., 1994). After slaughter, the meat content of carcasses is usually assessed on the basis of the weight of breast, thigh and leg muscles, while fat is measured by the weight of abdominal fat.

In earlier studies it was shown that the weight of the skin plus subcutaneous fat from the carcass, with the exception of the wings, is highly correlated $(r>0.98)$ with the total skin content along with subcutaneous and intramuscular fat in Peking duck (Bochno et al., 1998), goose (Bochno et al., 1995), mulard (Bochno et al., 1997), as well as turkey (Bochno et al., 1997) and chicken (Bochno et al., 1996) carcasses. It was also shown that the weight of the carcass without this part of the skin is highly correlated with the meat content of the whole carcass ( $r>0.96)$. Taking into account these results, we developed regression equations for the estimation of meat or fat plus skin content of the above breeds of water fowl (geese, ducks, and mulards) and the carcasses of turkeys and meat chickens of the heavy line CE-1.

This paper is a continuation of a previous study. The objective was to use the two mentioned traits, the weight of the skin plus subcutaneous fat and the skinned carcass, as independent variables in regression equations to estimate the meat and fat plus skin content of chicken carcasses of approximately six-week old broilers.

\section{MATERIAL AND METHODS}

The study was conducted on Avian Farms broiler chickens (67 males and 67 females) slaughtered at the age of six weeks. The birds were fed to appetite with standard feed mixture: starter (up to 3), grower (4 and 5) and finisher (6 week of age). The feeds contained: starter 19.9 and 12.9 ; grower and finisher $20.1 \%$ of crude protein and 13.4 MJ ME per $\mathrm{kg}$, respectively.

At the end of the rearing period the birds were fasted for approximately $12 \mathrm{~h}$, then slaughtered, plucked and eviscerated. The carcasses were cooled at $4^{\circ} \mathrm{C}$ for about $12 \mathrm{~h}$ then cut into parts (breast, leg, neck, wings, back), and these in turn, were dissected into meat, skin plus subcutaneous fat (SSF), intramuscular fat, and bones.

Data pertaining to the liveweight and the weight of abdominal fat, cooled carcass without abdominal fat, breast muscle (from half of the carcass), meat and SSF plus intramuscular and abdominal fat in the whole carcass, was used in the statistical analysis. Moreover, were determined: the weight of the skin and subcutaneous fat from the neck, legs, breast and back (without the wings), and the weight of the skinned carcass. These data were used to compute the correlation coefficients 
TABLE 1

Statistical mean $(\overline{\mathrm{x}})$ and coefficients of variability $(\mathrm{v})$ of analysed traits

\begin{tabular}{|c|c|c|c|c|c|}
\hline \multirow[t]{2}{*}{ Indices } & & & \multicolumn{3}{|c|}{ Sex } \\
\hline & & & $\sigma^{7}$ & 우 & mean \\
\hline \multicolumn{6}{|l|}{ Weight, $\mathrm{g}$} \\
\hline \multirow[t]{2}{*}{ before slaughter } & \multirow[t]{2}{*}{$X_{1}$} & $\bar{x}$ & $2579^{A}$ & $2142^{\mathrm{B}}$ & 2361 \\
\hline & & $\mathrm{v}$ & 6.93 & 7.93 & 11.84 \\
\hline \multirow[t]{2}{*}{ cold carcass } & \multirow{2}{*}{$\mathrm{X}_{2}$} & $\overline{\mathrm{x}}$ & $1848^{\mathrm{A}}$ & $1520^{\mathrm{B}}$ & 1684 \\
\hline & & $\mathrm{v}$ & 7.59 & 8.31 & 12.57 \\
\hline \multirow[t]{2}{*}{ carcass without skin } & \multirow[t]{2}{*}{$\mathrm{X}_{3}$} & $\overline{\mathrm{x}}$ & $1552^{\mathrm{A}}$ & $1252^{\mathrm{B}}$ & 1402 \\
\hline & & $\mathrm{v}$ & 7.72 & 8.02 & 13.29 \\
\hline \multirow[t]{2}{*}{$\mathrm{SSF}^{1}$} & \multirow[t]{2}{*}{$\mathrm{X}_{4}$} & $\overline{\mathrm{x}}$ & $296^{\mathrm{A}}$ & $267^{\mathrm{B}}$ & 281 \\
\hline & & $\mathrm{v}$ & 10.63 & 15.81 & 14.13 \\
\hline \multirow[t]{2}{*}{ breast muscles } & \multirow[t]{2}{*}{$\mathrm{X}_{5}$} & $\overline{\mathrm{x}}$ & $209^{A}$ & $174^{\mathrm{B}}$ & 191 \\
\hline & & $\mathrm{v}$ & 11.69 & 11.96 & 15.04 \\
\hline \multirow[t]{2}{*}{ abdominal fat } & \multirow[t]{2}{*}{$\mathrm{X}_{6}$} & $\overline{\mathrm{x}}$ & 64 & 65 & 64 \\
\hline & & $\mathrm{v}$ & 19.72 & 24.12 & 21.97 \\
\hline \multirow{3}{*}{$\begin{array}{l}\text { In the carcass, } \mathrm{g} \\
\text { meat }\end{array}$} & \multirow{3}{*}{$\mathrm{Y}$} & & & & \\
\hline & & $\bar{x}$ & $1055^{\mathrm{A}}$ & $853^{\mathrm{B}}$ & 954 \\
\hline & & $\mathrm{v}$ & 8.38 & 8.69 & 13.62 \\
\hline \multirow[t]{2}{*}{ skin with fat } & \multirow[t]{2}{*}{$\mathrm{Z}$} & $\overline{\mathrm{x}}$ & $360^{\mathrm{A}}$ & $323^{\mathrm{B}}$ & 341 \\
\hline & & $\mathrm{v}$ & 10.44 & 15.02 & 13.76 \\
\hline
\end{tabular}

A, $\mathrm{B}-\mathrm{P}<0.01$

${ }^{1}-\mathrm{SSF}-$ skin plus subcutaneous fat

between the meat or fat plus skin content in the whole carcass and the remaining traits, and to develop the regression equation.

The obtained regression equations were checked in terms of accuracy of estimation of variables using data from ISA Vedette boiler chickens slaughtered at 6 and 7 weeks of age ( 10 males and females in both age groups).

\section{RESULTS}

Statistical characteristics of the studied traits and correlation coefficients

The liveweight of chickens averaged $2361 \mathrm{~g}$ for both sexes, with roosters significantly surpassing hens both in terms of body weight ( 2579 and $2142 \mathrm{~g}$, respectively) and the remaining traits, with the exception of abdominal fat weight. The variability of fat content of carcasses was greater than meat content. 
TABLE 2 Single correlation coefficients ( $\mathrm{r}$ ) between analysed traits and the content of meat or fat with skin in the carcass

\begin{tabular}{|c|c|c|c|}
\hline \multirow[b]{2}{*}{ Indicies } & \multirow[t]{2}{*}{ Sex } & \multicolumn{2}{|c|}{ In the carcass } \\
\hline & & meat & fat with skin \\
\hline $\begin{array}{l}\text { Weight } \\
\text { before slaughter }\end{array}$ & 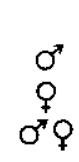 & $\begin{array}{l}0.879^{* *} \\
0.870^{* *} \\
0.951 * *\end{array}$ & $\begin{array}{l}0.773 * * \\
0.747 * * \\
0.735 * *\end{array}$ \\
\hline cold carcass & $\begin{array}{c}\sigma^{7} \\
\emptyset \\
\sigma^{\prime \prime} Q\end{array}$ & $\begin{array}{l}0.934 * * \\
0.925 * * \\
0.972 * *\end{array}$ & $\begin{array}{l}0.755^{* \prime} \\
0.731 * * \\
0.726 * *\end{array}$ \\
\hline SSF & 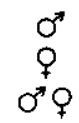 & $\begin{array}{l}0.503^{* *} \\
0.445^{* *} \\
0.550^{* *}\end{array}$ & $\begin{array}{l}0.972^{* *} \\
0.983^{* *} \\
0.981^{* *}\end{array}$ \\
\hline carcass without wings and SSF & $\begin{array}{c}0^{7} \\
0 \\
0^{7}+9\end{array}$ & $\begin{array}{l}0.961^{* *} \\
0.976^{* *} \\
0.987^{* *}\end{array}$ & $\begin{array}{l}0.628^{* *} \\
0.506^{* *} \\
0.615^{* *}\end{array}$ \\
\hline breast muscles & $\begin{array}{c}07 \\
\stackrel{+}{0} \\
0\end{array}$ & $\begin{array}{l}0.864^{* *} \\
0.863^{* *} \\
0.908^{* *}\end{array}$ & $\begin{array}{l}0.421^{* *} \\
0.331^{* *} \\
0.506^{* *}\end{array}$ \\
\hline abdominal fat & $\begin{array}{c}0^{7} \\
\text { q } \\
\text { ơ }\end{array}$ & $\begin{array}{l}0.343^{* *} \\
0.168 \\
0.138\end{array}$ & $\begin{array}{l}0.645^{* *} \\
0.732^{* *} \\
0.633^{* *}\end{array}$ \\
\hline
\end{tabular}

$* *-\mathrm{P}<0.01$

Among the examined traits, the skinned carcass weight was the most highly correlated with the carcass meat content $(r>0.96$; Table 2$)$. Slightly less correlated were whole carcass weight $(r>0.92)$, liveweight $(r>0.87)$, and breast muscle weight $(r>0.86)$.

In turn, the skin plus SSF weight was most highly correlated with the fat plus skin content $(r>0.97)$, which results from the high degree of autocorrelation of these traits; the weight of this skin part accounts for over $80 \%$ of total fat and skin of the whole carcass.

Regression equations and results of estimation of meat and fat contents in carcasses

Table 3 gives the regression equations computed on the basis of the data from birds of both sexes taken together $(1,3)$ and separately for males $(1 \mathrm{a}, 3 \mathrm{a})$ and females $(1 b, 3 b)$. Equations 3, 3a, and 3b, were obtained by stepwise regression initially taking into account a set of 6 traits (Table 1). Equations 1 , la and $\mathrm{lb}$ were developed taking into account only one dependent variable $\left(\mathrm{X}_{3}\right)$. 
TABLE 3

Regresion equations for estimation the meat $(\hat{\mathrm{Y}}, \mathrm{g})$ and skin with fat $(\check{\mathrm{Z}}, \mathrm{g})$ content in the carcass

\begin{tabular}{|c|c|c|c|c|}
\hline Equation & Sex & Equations & $\mathrm{S}_{\mathrm{Y} / \mathrm{Z}}$ & $\mathrm{R}$ \\
\hline 1 & $\sigma^{7}$ 우 & $\hat{\mathrm{Y}}=0.688 \mathrm{X}-10.44$ & 21.0 & 0.987 \\
\hline 1a & $\sigma^{7}$ & $\hat{Y}=0.709 X_{3}^{3}-45.81$ & 24.5 & 0.961 \\
\hline $1 \mathrm{~b}$ & q & $\hat{Y}=0.720 X_{3}-48.48$ & 16.4 & 0.976 \\
\hline 3 & శ’우 & $\check{Z}=1.158 X_{4}+15.37$ & 9.1 & 0.981 \\
\hline $3 a$ & $\sigma^{7}$ & $\check{Z}=1.161 X_{4}^{4}+16.38$ & 9.0 & 0.971 \\
\hline $3 b$ & q & $\check{Z}=1.130 \mathrm{X}_{4}^{4}+21.20$ & 9.0 & 0.983 \\
\hline
\end{tabular}

* $-\mathrm{X}_{3}$ and $\mathrm{X}_{4}-$ see Table 1

The developed equations were verified in terms of accuracy in estimating the meat and fat plus skin contents of carcasses. They were used for the numerical data from ISA Vedette broilers slaughtered at 6 and 7 weeks of age from another experiment (Bochno and Brzozowski, 1998).

Of the equations used to estimate the meat content of carcasses, equation number 1 with the skinned carcass weight $\left(\mathrm{X}_{3}\right)$ as the only dependent variable is noteworthy.

TABLE 4

Meat $(\hat{\mathrm{Y}})$ and fat with skin $(\check{\mathrm{Z}})$ content $(\mathrm{g})$ in the carcass estimated with regression equations

\begin{tabular}{|c|c|c|c|c|c|c|c|}
\hline & Equation & Weeks & Sex & In the & arcass, $\mathrm{g}$ & $\begin{array}{l}\text { Differen } \\
\text { Y-Y or } Z\end{array}$ & $\begin{array}{l}\text { orrelation } \\
\text { pefficient }\end{array}$ \\
\hline & & of life & & aktual & estimated & $\mathrm{g}$ & $R_{Y-\hat{Y}(Z-z z)}$ \\
\hline$\hat{\mathrm{Y}}$ & $\begin{array}{l}1 \\
1\end{array}$ & 6 & $\begin{array}{l}0^{7} \\
\text { o }\end{array}$ & $\begin{array}{l}889.2 \\
777.3\end{array}$ & $\begin{array}{l}887.4 \\
763.5\end{array}$ & $\begin{array}{r}1.8 \\
13.8\end{array}$ & $\begin{array}{l}0.98 \\
0.98\end{array}$ \\
\hline $\begin{array}{l}\hat{Y} \\
\hat{Y}\end{array}$ & $\begin{array}{l}1 \mathrm{a} \\
1 \mathrm{~b}\end{array}$ & & $\begin{array}{l}\sigma^{7} \\
\text { q }\end{array}$ & $\begin{array}{l}889.2 \\
777.3\end{array}$ & $\begin{array}{l}879.4 \\
761.5\end{array}$ & $\begin{array}{r}9.8 \\
15.8\end{array}$ & $\begin{array}{l}0.98 \\
0.99\end{array}$ \\
\hline$\check{Z}$ & $\begin{array}{l}3 \\
3\end{array}$ & & $\begin{array}{l}\sigma^{7} \\
\text { o }\end{array}$ & $\begin{array}{l}281.6 \\
275.4\end{array}$ & $\begin{array}{l}285.9 \\
282.7\end{array}$ & $\begin{array}{l}-4.3 \\
-7.3\end{array}$ & $\begin{array}{l}0.98 \\
0.99\end{array}$ \\
\hline $\begin{array}{l}\check{Z} \\
\check{Z}\end{array}$ & $\begin{array}{l}3 \mathrm{a} \\
3 \mathrm{~b}\end{array}$ & & $\begin{array}{l}0^{7} \\
\text { Q }\end{array}$ & $\begin{array}{l}281.6 \\
275.4\end{array}$ & $\begin{array}{l}287.9 \\
282.0\end{array}$ & $\begin{array}{l}-6.3 \\
-6.6\end{array}$ & $\begin{array}{l}0.98 \\
0.99\end{array}$ \\
\hline$\hat{\mathrm{Y}}$ & $\begin{array}{l}1 \\
1\end{array}$ & 7 & $\begin{array}{l}0^{7} \\
\text { o }\end{array}$ & $\begin{array}{l}1178.3 \\
1008.4\end{array}$ & $\begin{array}{r}1179.6 \\
997.9\end{array}$ & $\begin{array}{l}-1.3 \\
10.5\end{array}$ & $\begin{array}{l}0.98 \\
0.96\end{array}$ \\
\hline $\begin{array}{l}\hat{Y} \\
\hat{Y}\end{array}$ & $\begin{array}{l}1 \mathrm{a} \\
1 \mathrm{~b}\end{array}$ & & $\begin{array}{l}0^{7} \\
9\end{array}$ & $\begin{array}{l}1178.3 \\
1008.4\end{array}$ & $\begin{array}{l}1180.6 \\
1006.8\end{array}$ & $\begin{array}{r}-2.3 \\
1.6\end{array}$ & $\begin{array}{l}0.98 \\
0.96\end{array}$ \\
\hline$\check{Z}$ & $\begin{array}{l}3 \\
3\end{array}$ & & $\begin{array}{l}0^{7} \\
\text { q }\end{array}$ & $\begin{array}{l}388.0 \\
363.7\end{array}$ & $\begin{array}{l}378.3 \\
358.4\end{array}$ & $\begin{array}{l}9.7 \\
5.3\end{array}$ & $\begin{array}{l}0.99 \\
0.99\end{array}$ \\
\hline $\begin{array}{l}\check{Z} \\
\check{Z}\end{array}$ & $\begin{array}{l}3 \mathrm{a} \\
3 \mathrm{~b}\end{array}$ & & $\begin{array}{l}0^{7} \\
\text { q }\end{array}$ & $\begin{array}{l}338.0 \\
363.7\end{array}$ & $\begin{array}{l}380.6 \\
355.9\end{array}$ & $\begin{array}{l}7.4 \\
7.8\end{array}$ & $\begin{array}{l}0.99 \\
0.99\end{array}$ \\
\hline
\end{tabular}


It is characterized by a relatively low standard error of assessment $\mathrm{s}_{\mathrm{y}}=21 \mathrm{~g}$, which is $2 \%$ of the total meat content in the carcass. Also the estimates of the meat content in ISA Vedette broilers, both 6 and 7 week old, with the use of this equation were precise: the estimated values obtained were lower by an 1.8 to $13.8 \mathrm{~g}(0.20-1.78 \%)$, in comparison with the actual figures and the correlation coefficients for these variables were about 0.96 (Table 4 ). The results of estimation using the equations developed separately for males (1a) and females (1b) were similar.

Increasing the set of independent variables by including the weight of breast muscles from one half of the carcass did not decrease the standard error of estimation.

In the next equations, 3, 3a and $3 \mathrm{~b}$, the dependent variable was the total weight of SSF plus abdominal and intramuscular fat in the whole carcass. Among the initial six variables, only one was finally used in the equations - skin plus subcutaneous fat $\left(\mathrm{X}_{4}\right)$; the standard errors of estimation $\left(\mathrm{s}_{\mathrm{z}}\right)$ equaled $9 \mathrm{~g}(<3.3 \%$ of the fat plus skin content in the carcass; Table 3 ). The results of estimation of the content of skin plus subcutaneous fat in carcasses using these equations were very accurate: in the carcasses of 6-week-old roosters and hens, the results were overestimated by an average of from 4.3 to $9.3 \mathrm{~g}$, in the carcasses of 7-week-old birds, they were lower by 3.2 to $12.7 \mathrm{~g}$.

\section{DISCUSSION}

The main purpose of the conducted statistical analysis was to develop regression equations for the estimation of the meat and fat content in the carcasses of broiler chickens. Equations such as these are useful primarily for the assessment of the meat and fat content of birds used in experiments on improving the technology of producing chicken meat. They are usually carried out on chickens obtained by crossing various breeds of meat chickens. For this reason, the study was conducted using data on such chickens, which increased the utility of the developed equations for the estimation of the meat and fat content of broiler chicken carcasses. The equations developed previously for a heavy strain CE-1 (Bochno et al., 1996) are less accurate in estimating the meat and fat contents of broiler carcasses (unpublished results).

The presented results corroborate the conclusions drawn on the basis of earlier analyses of data on the carcasses of ducks, geese, as well a pure breed chickens (Bochno et al., 1995, 1996, 1998). They indicate also that the weight of the skin plus subcutaneous fat $\left(\mathrm{X}_{4}\right)$ is a very good indicator of the fat content of broiler carcasses as well $(r>0.97)$.

The second of the selected traits, weight of the carcass without the skin $\left(\mathrm{X}_{3}\right)$ turned out to be a very good indicator of the meat content of the whole carcass $(r \approx 0.97)$. Its measurement is very simple: the carcass is weighed after removing the skin. 
The developed regression equations taking into account the above two traits $\left(\mathrm{X}_{3}\right.$ and $\mathrm{X}_{4}$ ) as dependent variables are a reliable tool for the assessment of the meat and fat contents of broiler carcasses. It should be stressed that the results of these estimations in carcasses using equations developed from data for males, females, and jointly, were similar. Therefore, in order to simplify the evaluation of the meat and fat contents of rooster and hen carcasses, it can be recommended to use the equations developed from the data of both sexes together.

Equations 1 and 3 from Table 3 can also be recommended for use in experimental settings, as well as in chicken testing stations to estimate the carcass meat and fat plus skin contents, respectively. They are particularly useful for the evaluation of the slaughter value of broiler chickens used in experiments on improving the technology of production to obtain birds that have a high meat and low fat content.

\section{REFERENCES}

Bochno R., Brzozowski W., 1998. The effect of age and sex of broiler chickens on slaughter value, feed conversion and production costs. J. Anim. Feed Sci. 7, 63-72

Bochno R., Lewczuk A., Rymkiewicz J., 1997. The usability of the weight of skin slice with subcutaneous fat and the carcass without that slice for estimating the fatness and meatness of the whole young turkey carcasses. Proceedings of 13th European Symposium on the Quality of Poultry Meat, Poznań (Poland), pp. 613-618

Bochno R., Mazanowski A., Rymkiewicz J., 1998. Regression equations for estimating the meat and fat contents in duck carcasses with the weight of a skin slice with subcutaneous fat and the weight of the remaining part of the carcass as basic independent variables (in Polish). Acta Acad. Agric. Tech. Olst., Zoot. 48, 123-135

Bochno R., Rymkiewicz J., Brzozowski W., 1995. The weight of skin with subcutaneous fat from the carcass without wings as an index of fattness of the whole goose carcass. Proceeding of 10th European Symposium on Waterfowl, Halle (Germany), pp. 279-282

Bochno R., Rymkiewicz J., Salej T., 1996. The usefulness of the weight of a skin slice with subcutaneous fat and the weight of carcass without that slice for estimation of meatness and fatness of the whole carcasses of meat-type chickens (in Polish). Prz. hod., Zesz. nauk. Poultry Production and Breeding, No 24, 101-108

Bochno R., Wilkiewicz-Wawro E., Rymkiewicz J., 1997. Regression equations for estimating the content of lean and fat in carcasses of mule ducks. Proceedings of 11 th European Symposium on Watcrfowl, Nantes (France), pp. 625-631

Książiewicz J., Kontecka H., Nogowski L., 1994. Relationships between triglyceride concentration in blood and values of some traits in ducks determined on live birds and after slaughter in carcass. Rocz. Nauk. Zoot. 21, 61-68

Leenstra F. R., 1986. Effect of age, sex, genotype and environment on fat deposition in broiler chickens - A review. World Poultry Sci. J. 42, 12-25

Pingel H., Heimpold M., 1983. Effektivität der Selektion auf Lebendmasse und Brustfleischanteil bei Enten. Arch. Tierzucht 26, 435-444 


\section{STRESZCZENIE}

\section{Równania regresji do szacowania zawartości mięsa i thuszczu w tuszkach kurcząt brojlerów}

Sześćdziesiąt siedem samców i 67 samic kurcząt brojlerów Avian Farms odchowywano do wieku 6 tygodni i żywiono do woli standardowymi mieszankami paszowymi. Po zakończeniu odchowu kurczęta poddano ubojowi, a ich tuszki dysekowano na mięso, skórę z tłuszczem podskórnym, tłuszcz międzymięśniowy i kości.

Masa płata skóry z tłuszczem podskórnym z powierzchni tuszki z wyjątkiem skrzydeł $\left(\mathrm{X}_{4}\right)$ i masa tuszki bez tego płata $\left(\mathrm{X}_{3}\right)$ stanowią dobre wskaźniki odpowiednio odtłuszczenia $(\check{Z})(\mathrm{r}=0,97)$ i umięśnienia $(Y \hat{)})(\mathrm{r}=0,96)$ całych tuszek kurcząt brojlerów. Cechy te są stosunkowo łatwe do pomiaru.

Do wykorzystania w doświadczalnictwie można polecać następujące równania:

$$
\hat{Y}=0,6915 X_{3}-18,56 \text { oraz } \breve{Z}=1,1452 X_{4}+21,05 \text {. }
$$

